\title{
Pemberdayaan Pemuda Desa Dalam Strategi Promosi Digital Pada Desa Ledokombo Sebagai Desa Wisata Di Kabupaten Jember
}

\author{
Dediek Tri Kurniawan*1, Slamet Fauzan², Kennis Rozana ${ }^{3}$, Ahmad Fawaiq Suwanan ${ }^{4}$ \\ ${ }^{1}$ Departemen Manajemen, Fakultas Ekonomi, Universitas Negeri Malang \\ ${ }^{2}$ Departemen Akutansi, Fakultas Ekonomi, Universitas Negeri Malang \\ ${ }^{3}$ Departemen Biologi, FMIPA, Universitas Negeri Malang \\ ${ }^{4}$ Departemen Ekonomi Pembangunan, Fakultas Ekonomi, Universitas Negeri Malang \\ Jl Semarang No. 5 Malang, Jawa Timur \\ *Penulis Korespondensi. Email: dediek.kurniawan.fe@um.ac.id
}

\begin{abstract}
ABSTRAK
Desa Ledokombo memiliki tantangan yang berat. Sebagian besar pemuda desa yang kompeten memilih untuk meninggalkan desa untuk mendapatkan pekerjaan yang layak. Secara umum lulusan dari perguruan tinggi ternama enggan kembali ke Desa. Dampaknya desa memiliki kekurangan sumber daya manusia yang kompeten. Hal ini menjadi pekerjaan rumah bagi pengembangan desa. Disisi lain Desa Ledokombo memiliki potensi lain yakni terdapat tempat wisata yang menarik yaitu Kampung Belajar Tanoker. Sehingga diperlukan penguatan kapasitas desa dalam hal public enggagement melalui strategi promosi digital. Tujuan pengabdian ini adalah diseminasi informasi dan etalase produk yang dimiliki Desa Ledokombo melalui pembuatan website wisata Desa. Metode pelaksanaan pengabdian ini terbagi menjadi tiga tahap yaitu: tahap pertama preproduction, tahap kedua production, dan tahap ketiga postproduction. Tahapan production merupakan pelaksanaan programming yaitu terdiri dari Coding HTML/Flash, Scripting/Flash, Database, dan Content Management System. Konsep yang dibuat dalam website disesuaikan dengan ensensi dan identitas Desa Ledokombo. Hasil dari kegiatan pengabdian menunjukkan bahwa konsep wisata budaya perlu diangkat secara berkesinambungan. Pemuda desa yang memiliki pemahaman yang lebih baik terhadap teknologi informasi akan menjadi modal yang cukup dalam mempromosikan Desa Ledokombo sebagai desa wisata.
\end{abstract}

Kata Kunci: promosi digital, Ledokombo, desa wisata, Jember

\begin{abstract}
Ledokombo Village has a tough challenge. Most of the competent village youth chose to leave the village to find decent jobs. In general, graduates from well-known universities are reluctant to return to the village. As a result, the village has a lack of competent human resources. This is homework for village development. On the other hand, Ledokombo Village has another potential, namely there is an interesting tourist spot, namely the Tanoker Learning Village. So it is necessary to strengthen village capacity in terms of public engagement through a digital promotion strategy. The purpose of this service is to disseminate information and showcase products owned by Ledokombo Village through the creation of a Village tourism website. The method of implementing this service is divided into three stages, namely: the first stage of preproduction, the second stage of production, and the third stage of postproduction. The production stage is a programming implementation consisting of HTML / Flash coding, Scripting / Flash, Database, and Content Management System. The concept created on the website is adjusted to the essence and identity of Ledokombo Village. The results of the community service activities show that the concept of cultural tourism needs to be raised on an ongoing basis. Village youths who have a better understanding of information technology will provide sufficient capital in promoting Ledokombo Village as a tourist village.
\end{abstract}

Keywords: digital promotion, Ledokombo, tourist village, Jember 


\section{PENDAHULUAN}

Menurut laporan dari The Travel \& Tourism Competitiveness Report menyebutkan bahwa daya saing pariwisata indonesia mengalami kenaikan yang awalnya pada posisi ke 42 pada tahun 2017 menjadi posisi ke 40 pada tahun 2019. Hal ini mencerminkan bahwa pariwasata Indonesia memiliki daya tarik tersendiri di mata wisatawan, mengingat Indonesia sendiri merupakan negara dengan kekayaan dan keindahan alam yang tidak diragukan di mata dunia. Kenaikan daya saing sangat berdampak positif bagi Indonesia. Menurut Kementrian Pariwisata dan Ekonomi Kreatif (Kemenparkraf) menyebutkan bahwa pada tahun 2018 sendiri sektor pariwisata menyumbangkan 17 Miliar dolar devisa negara dan pada tahun 2019 sektor pariwisata menjadi penyumbang terbesar dari devisa negara mengalahkan sektor lain.

Kabupaten Jember merupakan daerah yang terletak di Jawa Timur. Tidak dipungkiri apabila Jawa Timur merupakan Provinsi yang mempunyai potensi wisata yang banyak, terutama wisata alamnya. Secara geografis Kabupaten Jember terletak pada posisi 627'29" s/d 7¹4'35" Bujur Timur dan 7059'6" s/d 833'56" Lintang Selatan berbentuk dataran ngarai yang subur bagian Tengah dan Selatan, dikelilingi pegunungan yang memanjang sepanjang batas (www.jemberinfo.com). Banyak objek wisata berupa pantai, bukit dan air terjun. Selain itu terdapat juga wisata berbasis edukasi, situs budaya, dan situs bersejarah. Banyak pesona dan panorama alam yang patut untuk dikembangkan. Salah satu tempat wisata menarik di Jember dan mempunyai potensi yaitu terletak di Desa Ledokombo.

Di Desa Ledokombo terdapat tempat wisata yang menarik yaitu Kampung Belajar Tanoker. Pada Kampung Belajar Tanoker Ledokombo memiliki banyak aktivitas wisata seperti kelas memasak, kelas seni, dan beberapa permainan tradisional. Pengembangan destinasi wisata menjadi kecenderungan bagi setiap daerah agar pariwisata yang ada semakin di kenal oleh khalayak luas. Usaha untuk mengembangkan pariwisata di Kampung Belajar Tanoker dibutuhkan inovasi dan sosisalisasi agar dapat meningkatkan jumlah pengunjung setiap tahunnya. Tanoker adalah komunitas belajar masyarakat ledokombo, kegiatan komunitas berfokus papda pengembangan potensi anak-anak melalui proses pengorganisasian dengan pendekatan budaya. Salah satu keunikan dari Komunitas Tanoker ini adalah penggunaan permainan tradisional sebagai medium untuk mengajarkan nilai-nilai kehidupan kepada anak.

Selain komunitas Tanoker, daya tarik lain adalah budaya di Ledokombo yang merupakan pencampuran etnis Madura dan etnis Jawa yang sering disebut "pendalungan". Proses interaksi antar ragam etnis ini terjadi sejak lama yang menghasilkan keunikan tersendiri. Akulturasi dua etnis tersebut dapat melahirkan bahasa Jawa dialek Madura (Jemberan), ludruk berbahasa Madura, kuliner dan sebagainya. Menurut Yuswadi (2001) dalam Roesfandi (2016) menjelaskan bila proses budaya Pendalungan berawal dari dua etnis (Maduran dan Jawa) yang mendiami wilayah yang sama. Kedua etnis yang saling membuka diri dan berpartisipasi terhadap budaya luar masuk ke budaya mereka sambil tetap mempertahankan buayanya. Keduanya menerima budaya tersebut secara damai.

Disamping potensi yang dimiliki oleh Desa Ledokombo, belum banyak orang yang tau tentang keberadaannya. Letaknya yang cukup jauh dari pusat kota Jember membuat desa ini tidak sering didengar. Hal tersebut juga disebabkan minimnya sosialisasi sehingga potensi wisata tersebut kurang dikenal di kalangan masyarakat luas. Penguatan brand melalui pengembangan startegi promosi efektif menjadi salah satu pendekatan terbaik yang dapat diambil dalam pengembangan desa wisata. Menurut konteks Brand (Wiryawan, 2008), pengertian tentang Place Branding adalah penerapan konsep dan model branding pada suatu tempat tertentu dapat berupa Negara, Provinsi atau Kota yang bertujuan untuk memaksimalkan potensi suatu daerah agar terjadi peningkatan kunjungan pada wisata maupun bisnis.

Sama seperti di perkotaan, pemuda di perdesaan juga sudah mampu mengadopsi perkembangan teknologi informasi baik smartphone, komputer, maupun internet. Pemuda di Desa Ledokombo juga memiliki ragam latar belakang pendidikan baik SMA, Diploma, dan Sarjana. Meskipun peran mereka di desa tersebut belum optimal, keberadaan pemuda desa dapat membantu optimalisasi kemajuan teknologi informasi dalam mengembangkan Desa Ledokombo sebagai 
destinasi desa wisata unggulan di kabupaten Jember.

Adapun rencana program melalui pelatihan dan pendampingan dan menghasilkan sebuah produk nyata bagi pengembangan desa wisata di desa Ledokombo. Dalam hal ini, muncul permasalahan mengenai kurangnya brand awareness dari Desa Ledokombo dalam proses pengenalan desa wisata di khalayak umum. Hal ini memunculkan sebuah inisiatif dalam melakukan kegiatan pemberdayaan pemuda desa dalam mempromosikan secara digital untuk meningkatkan brand awareness dari desa Ledokombo.

\section{METODE PELAKSANAAN}

Program pengabdian ini akan melibatkan beberapa pihak utama dalam menyukseskan kegiatan ini yaitu: pemuda desa, komunitas tanoker, pemerintah desa, dan pihak Universitas Negeri Malang. Pola pengumpulan peserta pelatihan adalah tim pelaksana pengabdian bekerjasama dengan perangkat Desa Ledokombo untuk menghubungi pemuda desa melalui organisasi seperti karang taruna dan organisasi lainnya setempat. Target jumlah total kuota peserta kegiatan ini sebanyak 20 orang peserta.

Kolaborasi semua pihak diharapkan mampu meningkatan sinergi antara kalangan desa dan akademisi untuk implementasi program yang ada. Adapun rencana program melalui pelatihan dan pendampingan dan menghasilkan sebuah produk nyata bagi pengembangan desa wisata di desa Ledokombo. Fokus program pengabdian ini adalah "Strategi Promosi Digital pada Peningkatan Brand Awareness terhadap Desa Ledokombo sebagai Desa Wisata Unggulan di Kabupaten Jember". sebagai berikut;

1. Persiapan

a) Penyusunan proposal

b) Identifikasi kebutuhan pelaksanaan program pengabdian masyarakat

c) Koordinasi dengan perangkat Desa Ledokombo

d) Perekrutan peserta pelatihan yang memiliki semangat tinggi untuk belajar dan berperan aktif di desa.

e) Pendataan peserta pelatihan seperti nama, usia, dan jenis produk lokal yang diproduksi. Agar menjadi salah satu database tim pelaksana.

2. Pelaksanaan Program a) Sosialisasi dan pemberian pengetahuan dan pemahaman mengenai strategi promosi digital dengan sharing session terkait tantangan dan persalahan yang dihadapi. Sosialisasi ini akan diberikan oleh pemateri dari Universitas Negeri Malang sebanyak dua kali pertemuan.

b) Pendampingan perencanaan konsep strategi promosi digital dalam peningkatan brand awareness Desa Ledokombo. Tim pelaksana akan mendampingi pemuda desa dalam menyusun strategi promosi digital. Pendampingan ini tidak semata dilakukan secara langsung tapi juga melalui media daring.

c) Program pendampingan untuk membuat output nyata sebuah promosi digital promosi digital sehingga pemuda desa mampu memiliki peran aktif membangun Desa Ledokombo sebagai desa wisata.

3. Evaluasi Program

a) Mencatat permasalahan-permasalahan yang muncul selama proses pelatihan.

b) Mengevaluasi antusias peserta, baik itu umpan balik dan respon dari peserta pelatihan.

c) Membuat notulensi pelaksanaan kegiatan.

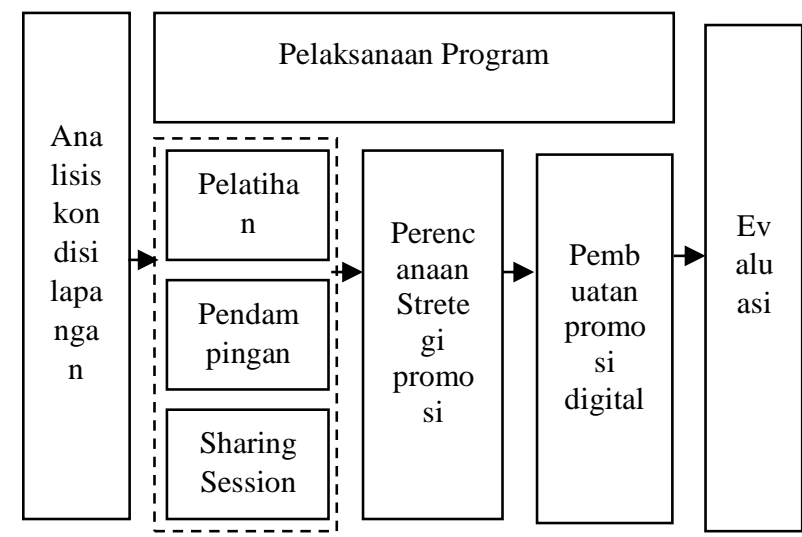

Gambar 1. Rancangan Program

Pengabdian Masyarakat 
Ledokombo dalam memajukan potensi wisata. Kegiatan dilakukan dengan melakukan diskusi seputar tantangan yang dihadapi Kepala Desa Ledokombo dalam membangun potensi wisata. Kepala Desa Ledokombo saat ini dijabat oleh Bapak Ipunk Wahyudi. Dengan usia yang masih tergolong muda, Bapak Ipunk Wahyudi memiliki visi dan misi menjadikan Desa Ledokombo salah satu destinasi unggulan di Jember. Meskipun demikian, mewujudkan hal itu menjadi nyata adalah tantangan yang cukup berat. Hal ini berkaitan dengan kondisi dan karakteristik dari masyarakat di Desa Ledokombo. Bukanlah hal yang mudah mengajak masyarakat di Desa Ledokombo untuk berpartisipasi dalam kegiatan/program desa. Di samping menjadi potensi wisata budaya, pendalungan menjadi tantangan bagi kepala desa. Hal ini berkaitan karakter yang berbeda dari etnis Jawa dan etnis Madura asli. Hal tersebut menjadi tantangan bagi kepala desa di Desa Ledokombo untuk melakukan pendekatan pada warga di sana.

Keberadaan pendalungan di Desa Ledokombo tidak terlepas dari lokasinya berada di pinggiran kota. Perpaduan dan adaptasi budaya yang terjadi lebih banyak berlangsung di pusat dan pinggiran kota (Satrio, 2019). Salah satu yang sangat terlihat ketika interaksi antara warga Madura dan Jawa melahirkan sebuah Bahasa Jawa Dialek Jember yang mempunyai perbedaan dalam struktur dengan Bahasa Jawa pada umumnya.

\section{HASIL DAN PEMBAHASAN}

Program pengabdian ini terbagi menjadi dua tahap yaitu: tahap 1 preproduction, tahap 2 production, dan tahap 3 postproduction.

\section{Tahap 1 Preproduction}

Pada tahap ini dilakukan penggalian data dan informasi terkait permasalahan yang terjadi di lapangan. Pada tahap ini dilakukan yaitu pengumpulan data dan pengumpulan konten. Pengumpulan data dimaksudkan untuk memahami lebih detail terhadap potensi wisata di Desa Ledokombo dan permasalah yang mungkin dihadapi dalam mewujudkan desa wisata.

\section{Kegiatan diskusi dengan Kepala Desa Ledokombo}

Pada tahap ini juga dilakukan sharing session terkait pengembangan wisata di Desa Ledokombo dan kemungkinan peran yang dapat dilakukan oleh pemuda desa di

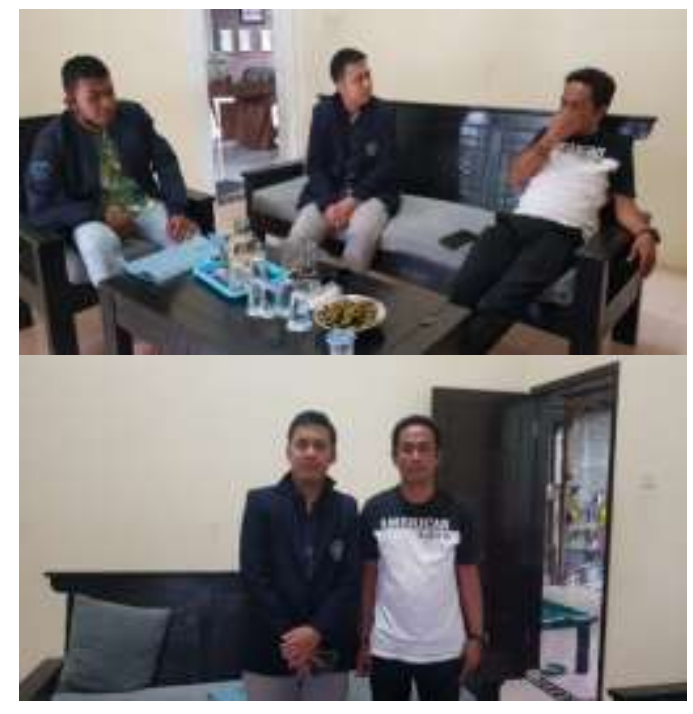

Gambar 1. Kegiatan Diskusi dengan Kepala Desa Ledokombo 
Anjasmoro (di Desa Sumbersalak). Selain itu, keberadaan desa Ledokombo juga menjadi jalur yang dilewati bila menuju Kecamatan Sumberjambe yang memiliki potensi wisata alam seperti Air Terjun 7 bidadari (Sumberjambe), Air Terjun Lereng Raung (Sumberjambe). Mereka biasanya lulusan dari perguruan tinggi ternama dan enggan kembali ke Desa. Hal ini juga menjadi pekerjaan rumah bagi pengembangan desa.

Pemetaan potensi desa yang dimiliki Desa Ledokombo juga menjadi pembahasan dalam kegiatan ini. Berdasarkan pemaparan dari Kepala Desa adapun perencanaan Desa Ledokombo adalah:

1) Desa Ledokombo memiliki Tanoker yang menjadi icon dari Desa Ledokombo yang lebih mengedepankan wisata budaya. Keberadaan Tanoker sendiri sudah lebih dulu dikenal oleh masyarakat luas di luar Jember. Hal ini memungkinkan Desa Ledokombo untuk menguatkan keberadaannya dalam mengembangkan potensi wisata yang lain.

2) Pengembangan wisata berbasis budaya. Desa Ledokombo tidak memiliki alam yang menonjol di bandingkan desa sekitarnya seperti Desa Sumberlesung, Desa Sumber Salak, Desa Sumberjambe. Hal itu mendorong adanya perencaanaan konsep wisata budaya yang akan diangkat dimana pelestariaan budayabudaya dengan rencana pembuatan tempat atraksi budaya di taman desa yang tengah dibangun.

3) Pengembangan wisata kuliner yaitu potensi makanan tradisional di Desa Ledokombo. Meskipun kuliner di Desa Ledokombo tidak jauh berbeda dengan makanan khas di desa lain di Kabupaten Jember, potensinya masih baik untuk menarik wisatawan.

4) Penempatan Desa Ledokombo sebagai pusat wisata yang mengangkat desa sekitarnya yaitu Desa Sumberlesung, dan Desa Sumbersalak. Hal ini berkaitan dengan potensi wisata yang ada di desa-desa tersebut seperti Air Terjun Ledokombo (di Desa Sumber Lesung), Air Terjun Damar Wulan (di Desa Sumbersalak), dan Air Terjun
Tabel 1. Potensi Wisata Desa Ledokombo

\begin{tabular}{|c|c|}
\hline $\begin{array}{l}\text { Macam } \\
\text { Wisata }\end{array}$ & Wisata yang ada saat ini \\
\hline Wisata & 1. Belajar membuat kerajinan khas \\
\hline Edukasi & 2. Belajar memasak ala Ledokombo \\
\hline \multirow[t]{9}{*}{ Wisata Atraksi } & 1. Polo Lumpur \\
\hline & 2. Bakiak \\
\hline & 3. Egrang \\
\hline & 4. Kakean (Gasing) \\
\hline & 5. Petak Umpet \\
\hline & 6. Kelereng \\
\hline & 7. Dakon (Congklak) \\
\hline & 8. Gobak Sodor \\
\hline & 9. Layangan \\
\hline Wisata & Agrowisata dengan tanaman unggulan \\
\hline Tanoargo & $\begin{array}{l}\text { seperti ketela pohon, ketela rambat, } \\
\text { dan padi organik }\end{array}$ \\
\hline Wisata & 1. Tari Egrang dan Perkusi \\
\hline \multirow[t]{3}{*}{ Budaya } & 2. Festival Egrang \\
\hline & 3. Pertunjukan jalanan "Sound Mini" \\
\hline & 4. Musik Patrol \\
\hline Wisata & Ragam masakan khas Tanoker \\
\hline \multirow[t]{13}{*}{ Kuliner } & 1. Nasi Hijau \\
\hline & 2. Mie Telo \\
\hline & 3. Sate Jamur \\
\hline & Kudapan khas \\
\hline & 1. Puding Pepaya \\
\hline & 2. Roti Ledokombo \\
\hline & 3. Kue Jengkong \\
\hline & 4. Lapis Batik \\
\hline & 5. Apem Takir \\
\hline & 6. Klepon Telo \\
\hline & 7. Keripik Bawang \\
\hline & 8. Kue Ulat Sutra \\
\hline & 9. Teh Arab \\
\hline \multirow[t]{3}{*}{ Wisata Alam } & 1. Air Terjun Damarwulan \\
\hline & 2. Air Terjun Antrokan \\
\hline & 3. Air Terjun Anjasmoro \\
\hline Homestay & Pondok-pondok desa \\
\hline
\end{tabular}

\section{Kegiatan sosialisasi dengan pemuda desa}

Kegiatan kedua yang dilakukan adalah sharing session dan sosialisasi potensi pengembangan desa wisata. Dalam kegitan ini pelaksana menggunakan Bahasa Madura untuk memudahkan pemahaman pemuda desa yang merupakan bahasa sehari-hari. Kegiatan diskusi ini merupakan ajang sharing session yang bertujuan untuk menyamakan persepsi bagi pemuda desa dan tim mengenai tantangan dan masalah yang dihadapi untuk meningkatkan awareness dari wisata tersebut. Selain itu, diskusi ini diadakan guna memperkenalkan maksud dan tujuan dari kegiatan pengabdian ini sehingga adanya diskusi ini masyarakat desa 
meningkatkan konsumen tentang spesifikasi produk atau merek.

program yang akan dilakukan. Sosialisasi merupakan proses pemberian informasi dan pemahaman mengenai program yang akan di rencanakan oleh tim, dalam proses sosialisasi tim akan memberikan gambaran sebuah desa wisata dan strategi promosi digital yang tepat sehingga mampu meningkatkan brand awareness dari wisata di desa Ledokombo. Sosialisasi akan diberikan oleh pemateri dari tim pengabdian Universitas Negeri Malang.



Gambar 2. Kegiatan Diskusi dengan Tokoh Pemuda Desa Ledokombo

Disamping kegiatan itu, kegiatan dilanjutkan dengan pemaparan mengenai perencanaan langkah-langkah melakukan strategi pemasaran digital dengan pemanfaatkan social media, dan juga pelatihan pembuatan content marketing yang mampu menarik calon wisatawan. Pelatihan ini akan berfokus pada pendampingan secara intensif mengenai pembuatan konten-konten promosi output luaran yang ingin dicapai adalah pemuda desa mampu menyusun strategi promosi digital melalui pembuatan konten kreatif. Promosi adalah tindakan menginformasikan atau

\begin{tabular}{|l|l|l|}
\hline \multicolumn{1}{|c|}{ Tipe Pelatihan } & \multicolumn{1}{|c|}{ Konten } & \multicolumn{1}{c|}{ Peserta } \\
\hline $\begin{array}{l}\text { Metode } \\
\text { Pengalaman } \\
\begin{array}{l}\text { Praktis (Hand-on } \\
\text { Method) }\end{array}\end{array}$ & $\begin{array}{l}\text { Penyususunan } \\
\text { kerangka strategi } \\
\text { promosi digital }\end{array}$ & $\begin{array}{l}\text { Pemuda } \\
\text { Desa } \\
\text { Ledokombo }\end{array}$ \\
\hline $\begin{array}{l}\text { Metode } \\
\text { Pengalaman } \\
\text { praktik }\end{array}$ & $\begin{array}{l}\text { Pembuatan } \\
\text { konten marketing } \\
\text { yang menarik }\end{array}$ & $\begin{array}{l}\text { Pemuda } \\
\text { Desa } \\
\text { Ledokombo }\end{array}$ \\
\hline
\end{tabular}

Tabel 2. Metode Pendampingan Pemuda Desa Ledokombo

\section{Tahap 2 Production}

Pada tahap ini, pelaksana pengabdian telah menetapkan pembuatan website dan sosial media instagram sebagai strategi pemasaran yang akan dilaksanakan. Pembuatan konten juga akan dibantu oleh tenaga ahli mahasiswa dari Universitas Negeri Malang. Hal ini berkaitan dengan bagaimana proses pendampingan dan pelatihan akan membutuhkan waktu yang lama sampai menghasilkan konten yang sesuai dengan harapan. Peran pemuda desa nantinya akan mengoperasikan website baru wisata Ledokombo dan sosial media. Oleh karena itu, mereka fokus menyiapkan konten bukan membuat sarana website dan sosial media.

\section{Pembuatan Website Wisataledokombo Jember}

Pada tahapan production pada website, pelaksana menetapkan pembuatan website yang sesuai dengan kebutuhan desa. Hal tersebut juga disuarakan oleh Kepala Desa Ledokombo yang merasa pentingnya keberadaan website dalam memperkenalkan Desa Ledokombo lebih luas lagi. Penetapan logo adalah hal pertama sebagai bagian strategi branding dari website desa. Untuk domain yang dipilih adalah wisataledokombo.com yang dianggap lebih cocok dengan tujuan pembuatan websute ini. Penetapan tujuan website adalah sarana informasi mengenai desa dan potensi wisata di Desa Ledokombo. Selain itu, website ini juga akan dirancang mampu mengakomodasi produk-produk yang 
dalam updating situs; (3) Kebutuhan standar instalasi sangat rendah; (4) Dilengkapi dengan fasilitas Spam Protection dan sistem password protected yang baik; (5) Fokus di dalam estetika, web standard dan kemudahan; (6) Menggunakan bahasa script yang "terbuka" (open source) hingga memungkinkan ditambahkan dengan plug-in, widgets, hingga dapat memaksimalkan fungsi dan kebutuhan dari situs; (7) Memiliki fasilitas user regristration dan multiple authors yang baik, (8) WordPress berkembang dengan sangat pesat.

Tahapan programming dilakukan oleh tenaga expert dari dosen dan mahasiswa Univerasitas Negeri Malang dalam mewujudkan website tersebut. Tahapan itu juga meliputi membangun management system yang diperlukan.

kesederhanaan. Permainan-permainan yang ditampilkan juga sesuai dengan salah satu destinasi unggulan di Desa Ledokombo yaitu Ledokombo.



Gambar 3. Ilustrasi Desa Ledokombo

Proses berikutnya pada tahapan production adalah programming yaitu terdiri dari Coding HTML/Flash, Scripting/Flash, Database, dan Content Management System. Pada proses ini, pelaksana program menggandeng dosen Universitas Negeri Malang yang memiliki pengetahuan dan keterampilan yang cukup dalam membuat website ini. Proses ini juga membangun halaman admin yang disesuaikan dengan kebutuhan dan mudah digunakan bagi siapa pun. Penggunaan CMS adalah menggunakan WordPress. Widhyatmoko (2010) menyampaikan alasan mengenai pengunaan engine WordPress adalah: (1) Free SoftwareOpen Source Software; (2) Mudah dalam instalasi dan operasional, terutama kemudahan

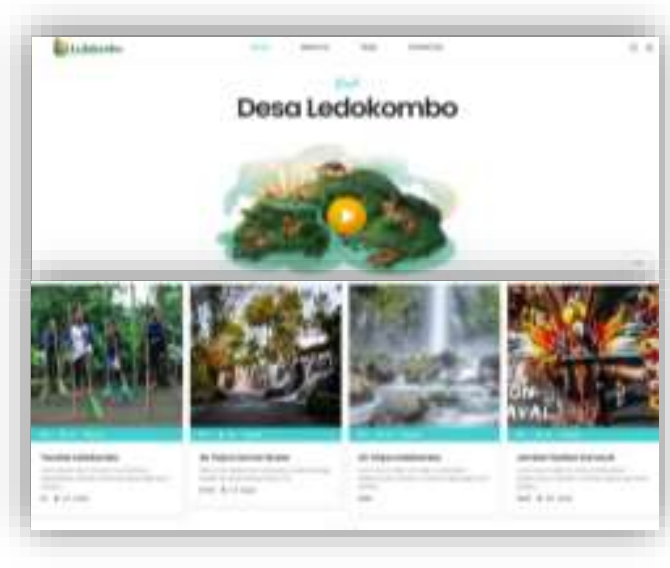

Gambar 4. Welcome Page pada Website Wisata Ledokombo

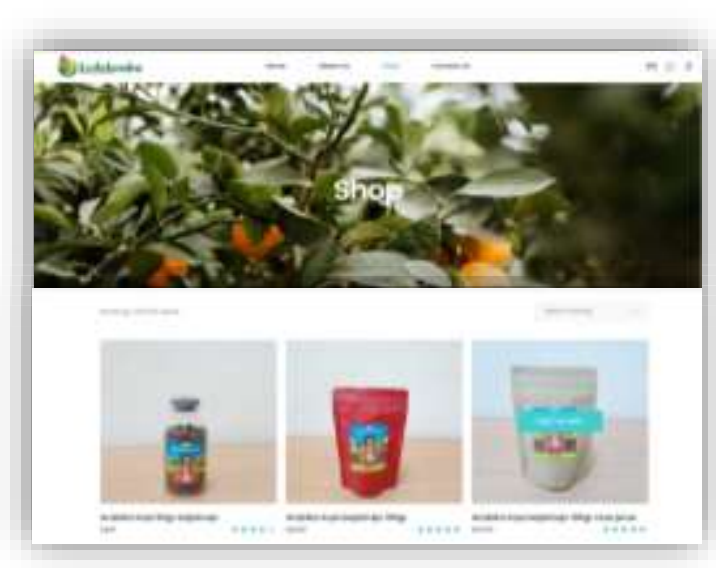

Gambar 5. Product Display Page pada Website Wisata Ledokombo 
Peran pemuda desa menjadi strategis

Hasil survey APJII 2018, pengguna internet di Indonesia mencapai 150 juta jiwa. Dari data tersebut, sosial media tidak dapat terpisahkan dari kehidupan masyarakat di Indonesia. Berdasarkan databoks Katadata.co.id, rata-rata waktu yang dihabiskan masyarakat Indonesia untuk mengakses sosial media selama 3 jam 26 menit. Total pengguna aktif sosial media sebanyak 160 juta atau 59\% dari total penduduk Indonesia. 99\% pengguna media sosial berselancar melalui ponsel. Hal itu juga menjadi alasan dalam pembuatan sosial media instagram sebagai strategi promosi digital Desa Ledokombo. Nama yang ambil dalam mempromosikan Desa Ledokombo melalui Instagram adalah wisata_ledokombo. Instagram Wisata Ledokombo nantinya akan dikelola oleh pemuda desa di sana untuk dimaksimalkan perannya dalam meningkatkan promosi Desa Ledokombo sebagai desa wisata.

Gambar 6. Instagram Wisata Ledokombo

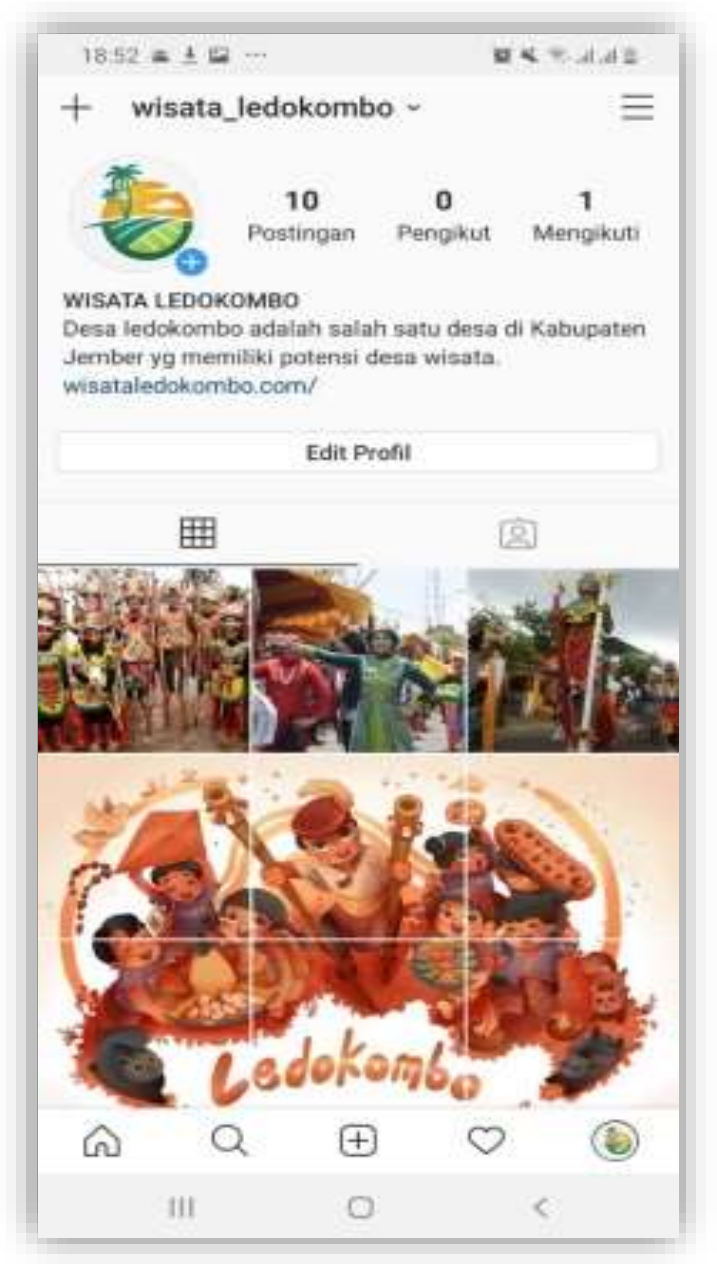

KESIMPULAN dalam pengelolaan promosi digital Desa Ledokombo. Fokus program pengabdian ini adalah Pemberdayaan Pemuda Desa dalam Strategi Promosi Digital terhadap Desa Ledokombo sebagai Desa Wisata Unggulan di Kabupaten Jember. Pemuda desa yang memiliki lebih baik pemahaman terhadap teknologi informasi akan menjadi modal yang cukup dalam mempromosikan Desa Ledokombo sebagai desa wisata. Berdasarkan penggalian data, program dikhususkan dalam pembuatan website desa dan Instagram. Website wisata Desa Ledokombo ternyata memang merupakan salah satu kebutuhan yang disuarakan oleh Kepala Desa Ledokombo. Konsep yang dibuat dalam website disesuaikan dengan ensensi dan identitas Desa Ledokombo. Tujuan pembuatan website wisata Desa Ledokombo adalah saran informasi dan etalase produk yang dimiliki Desa Ledokombo. Selain itu, keberadaan instagram wisata_ledokombo juga menguatkan strategi promosi digital dalam memperkenalkan Desa Ledokombo sebagai desa wisata unggulan di Kabupatan Jember. Kedua sarana tersebut baik website dan Instagram wisata Ledokombo diharapkan dikelola baik oleh pemuda desa di Ledokombo secara berkelanjutan.

\section{SARAN}

Segenap pemangku kepentingan (stakeholders) desa perlu memperkuat identitas dan brand Desa Ledokombo melalui website dan sosial media yang sudah terbangun. Hasil dari kegiatan pengabdian menunjukkan bahwa konsep wisata budaya menjadi keunggulan Desa Ledokombo, untuk itu perlu diangkat secara berkesinambungan dan terus dilestarikan. Pemuda desa yang memiliki pemahaman terhadap teknologi informasi akan menjadi modal penting dalam mempromosikan Desa Ledokombo sebagai desa wisata. Sehingga diperlukan kegiatan pengabdian lanjutan dalam rangka meningkatkan level kompetensi pemuda desa untuk pengembangan wisata desa berbasis budaya.

\section{UCAPAN TERIMAKASIH}


pariwisata-diproyeksikan-jadipenyumbang-devisa-terbesar-limatahun-ke-depan .Online. (diakses pada 19 Maret 2020)

membantu dalam pelaksanaan pengabdian ini dan semoga program ini bermanfaat bagi masyarakat setempat. Penulis menyampaikan terima kasih juga kepada Universitas Negeri Malang yang memberikan dukungan penuh baik secara materi atau non-materi dalam pengabdian ini.

\section{DAFTAR PUSTAKA}

Aptika Kominfo. 2019. Penggunaan Internet di Indonesia.https://aptika.kominfo.go.id/2 019/08/penggunaan-internet-diindonesia/\#: :text=Di\%20Indonesia\%2 C\%20pengguna\%20internet\%20mencap ai,dengan \%20persentase $\% 20$ penetrasi $\%$ 20 sebesar\%2053\% 25 .

Disbudpar. 2019. Angka Kunjungan Wisatawan Ke NTB. http://www.disbudpar.ntbprov.go.id/ang ka-kunjungan-wisatawan-ke-ntb/angkakunjungan-wisatawan-tahun-20132015/angka-kunjungan-wisatawan2019/angka-kunjungan-wisatawantriwulan-ii-2019/ . Online. (diakses pada 14 Desember 2019)

Gerry Barnas Saputra, Muksin, Merry Muspita. 2018. Pengembangan agrowisata di Kecamatan Ledokombo. Jurnal Pengabdian Masyarakat 2.

Gusdurian. 2020. Sosok Multikulturalisme Ala Tanoker Ledokombo. http://www.gusdurian.net/id/sosok/Mult ikulturalisme-Ala-Tanoker-Ledokombo/ .online. (diakses pada 19 Maret 2020)

Juhanda. 2018. Pemancangan merek (brand) 'tanoker' di desa wisata sumber lesungledok ombo-jember sebagai pembeda daya tarik wisata perdesaan. Jurnal Kepariwisataan dan Hospitalitas 2 (2).

Kemenparekraf. 2020/ Siaran Pers Pariwisata Diproyeksikan Jadi Penymbang Devisa Terbesar Lima Tahun Kedepan.http://www.kemenparekraf.go. id/index.php/post/siaran-pers-
Kompas. 2019. Sepanjang 2019 Kunjungan Wisman Ke Bali Dari Sejumlah Negara Meningkat.https://www.google.co.id/am p/s/amp.kompas.com/travel/read/2019/1 0/10/211500427/sepanjang-2019kunjungan-wisman-ke-bali-darisejumlah-negara-meningkat . Online. (diakses pada 14 Desember 2019)

Radar Jember. 2019. https://radarjember.jawapos.com/headli ne/20/07/2019/dubes-australiakunjungi-wisata-perdamaian/ .Online. (diakses pada 19 Maret 2020)

Roestfandi, P. S. 2016. Keluarga pendalungan, keluarga berbasis budaya Madura atau Jawa. Prosiding Psychofest 2016.

Satrio, P. 2019. Transmisi budaya dan identitas sosial pada masyarakat Pendalungan. Prosiding Seminar Nasional \& Call Paper Psikologi Sosial 2019

Tanoker. 2019. Kampung Wisata Belajar Ledokombo.https://tanoker.org/kampun g-wisata-belajar-ledokombo/.Online. (diakses pada 14 Desember 2019)

Tribun News. 2019. Jumlah Kunjungan Wisatawan Di Yogyakarta Terus Alami Peningkatan Tiap Tahun. https://www.google.co.id/amp/s/jogja.tri bunnews.com/amp/2019/11/05/jumlahkunjungan-wisatawan-di-kotayogyakarta-terus-alami-peningkatantiap-tahun . Online. (diakses pada 14 Desember 2019)

Widhyatmoko, D. 2010. Rancangan Pembuatan Website Jurusan Desain Komunikasi Visual (Dkv) Universitas Bina Nusantara. Humaniora 1 (2), 233-245.

Wiryawan, Mendiola. (2008). Kamus Brand. Jakarta: Red and White Publishing. 